\title{
PROFILE OF WOMEN WITH LEG ULCERS DUE TO SICKLE CELL DISEASE
}

\author{
Paula Gabriela Andrade ${ }^{1, *}$ (D), Josimare Aparecida Otoni Spira² (D), \\ Maria de Lourdes Gomes ${ }^{4}$, Eline Lima Borges ${ }^{3}$
}

\begin{abstract}
Objective: to characterize the profile of women with leg ulcers resulting from sickle cell disease treated at a public health institution in Brazil. Method: historical cohort study conducted in the outpatient sector with a sample of women with sickle cell disease and leg ulcer, followed from 1998 to 2014. The data were extracted from the medical record and included sociodemographic, clinical and ulcer-related variables, and underwent descriptive statistical analysis. Results: of the 17 women, $64.7 \%$ were cured, 58.8\% were aged between 30 and 39 years, 64.7\% declared themselves brown, $70.6 \%$ were without partners, $41.2 \%$ had incomplete elementary education, 52, 9\% had an income of 2 to 3 minimum wages, $70.6 \%$ were eutrophic and $82.4 \%$ used vitamin supplements. Women had a total of 29 ulcers, $52.9 \%$ had a single ulcer, $41.4 \%$ were located in the malleolar region, $55.17 \%$ were between 2 and 36 months, all classified as stage 3. The treatment was with coverings and Unna's boot. Conclusion: the women received care from specialist nurses and most were cured with up to eight months of follow-up, which required a nursing consultation, including clinical evaluation, topical treatment and application of compression therapy.
\end{abstract}

DESCRIPTORS: Sickle cell anemia. Leg ulcer. Health profile. Stomatherapy.

\section{PERFIL DE MULHERES COM ÚLCERAS DA PERNA DECORRENTES DE DOENÇA FALCIFORME}

\section{RESUMO}

Objetivo: caracterizar o perfil de mulheres com úlceras da perna decorrentes da doença falciforme atendidas em uma instituição pública de saúde do Brasil. Método: estudo de coorte histórica realizado no setor ambulatorial com amostra de mulheres com doença falciforme e úlcera da perna, acompanhadas de 1998 a 2014. Os dados foram extraídos do prontuário e contemplaram variáveis sociodemográficas, clínicas e relacionadas à úlcera, e passaram por análise estatística descritiva. Resultados: das 17 mulheres, 64,7\% obtiveram cura, 58,8\% tinham idade entre 30 e 39 anos, 64,7\% se autodeclaram pardas, 70,6\% estavam sem parceiros, 41,2\% possuíam ensino fundamental incompleto, 52,9\% tinham renda de 2 a 3 salários mínimos, 70,6\% eram eutróficas e 82,4\% faziam uso de suplementos vitamínicos. As mulheres apresentaram o total de 29 úlceras, 52,9\% tinham úlcera única,

1. Universidade Federal de Minas Gerais - Hospital das Clínicas - Ambulatório de Dermatologia - Belo Horizonte (MG), Brazil.

2. Universidade Federal de Minas Gerais - Escola de Enfermagem - Belo Horizonte (MG), Brazil.

3. Universidade Federal de Minas Gerais - Escola de Enfermagem - Departamento de Enfermagem Básica -

Belo Horizonte (MG), Brazil.

4. Escola Bahiana de Medicina e Saúde Pública - Salvador (BA), Brazil.

*Correspondence author: paula_gabriela11@yahoo.com.br

Section Editor: Juliano T Moraes

Received: Dec. 14, 2020 | Accepted: Jan. 18, 2021

How to cite: Andrade PG; Spira JAO; Gomes ML; Borges EL. Profile of women with leg ulcers due to sickle cell disease. ESTIMA, Braz. J. Enterostomal Ther., 2021, 19: e0321. https://doi.org/10.30886/estima.v19.993_IN 
41,4\% localizadas na região maleolar, 55,17\% com existência entre 2 e 36 meses, todas classificadas em estágio 3. O tratamento foi com coberturas e bota de Unna. Conclusão: as mulheres receberam cuidados de enfermeiros especialistas e a maioria obteve a cura com até oito meses de acompanhamento que demandou a consulta de enfermagem, contemplando a avaliação clínica, o tratamento tópico e aplicação da terapia de compressão.

DESCRITORES: Anemia falciforme. Úlcera da perna. Perfil de saúde. Estomaterapia.

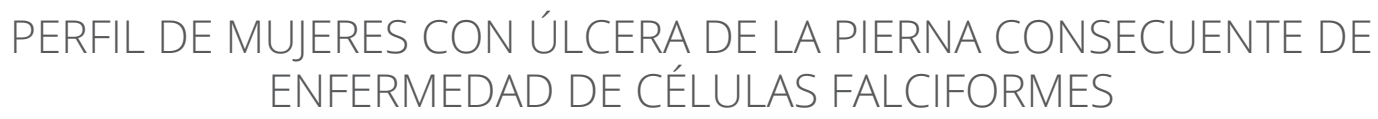

\title{
RESUMEN
}

\begin{abstract}
Objetivo: caracterizar el perfil de mujeres con úlceras de la pierna consecuente de enfermedad de células falciformes atendidas en una institución pública de salud de Brasil. Método: estudio de cohorte histórica realizado en el sector ambulatorio con muestra de mujeres con enfermedad de células falciformes y úlcera de pierna, seguidas de 1998 a 2014. Los datos fueron extraídos de la ficha médica y abarcaron las variables sociodemográficas, clínicas y relacionadas con la úlcera y pasaron por análisis estadístico descriptivo. Resultados: de las 17 mujeres, el 64,7\% obtuvieron curación, el 58,8\% tenían edades entre 30 y 39 años, el 64,7\% se autodeclararon morenas, el 70,6\% no tenían pareja, el 41,2\% no habían completado la educación básica, el 52,9\% con ingresos de 2 a 3 sueldos mínimos, el 70,6\% eran eutróficas, el 82,4\% hacían uso de suplementos vitamínicos. Las mujeres presentaron un total de 29 úlceras, el 52,9\% tenían úlcera única, el 41,4\% ubicadas en la zona maleolar; el 55,17\% con existencia entre 2 y 36 meses, todas clasificadas en estadio 3. El tratamiento se dio con vendajes y bota de Unna. Conclusión: las mujeres recibieron cuidados de enfermeros especialistas y la mayoría obtuvo la curación con hasta ocho meses de seguimiento. Fueron sometidas a la consulta de enfermería, comprendiendo la evaluación clínica, el tratamiento tópico y la aplicación de terapia de compresión.
\end{abstract}

DESCRIPTORES: Anemia de Células Falciformes; Úlcera de la Pierna; Perfil de salud; Estomaterapia.

\section{INTRODUCTION}

Sickle cell disease (SCD) comprises a group of genetic and hereditary diseases caused due to a mutation in the structural gene of the $\beta$-globin chain, resulting in hemoglobin $\mathrm{S}(\mathrm{HbS})$. When deoxygenated, $\mathrm{HbS}$ undergoes the polymerization process, with a consequent change in the shape of the erythrocyte (sickle shape), resulting in early hemolysis and occlusion of the vessels, which leads to several clinical repercussions ${ }^{1}$.

$\mathrm{HbS}$ can be found in homozygous and heterozygous states, the first being the most severe form of the disease, called sickle cell anemia (HbSS). The heterozygous state, caused by the HbS inheritance in combination with another mutation in hemoglobin A (HbA), appears in several forms, the most common being $\mathrm{S}$ beta-thalassemia, $\mathrm{S}$ alphathalassemia, HbSC, HbSD, HbSE${ }^{1}$.

SCD is more frequent in African, Mediterranean, Asian and Chinese peoples, although hemoglobinopathies that have ethnic predilections are present on all continents as a result of population migration. In Brazil, due to the great presence of afro-descendants who are one of the bases of the country's population, SCD constitutes a group of relevant diseases and conditions. The incidence is highest in the states with the highest concentration of Afrodescendants, being 1: 650 in Bahia, 1: 1,200 in Rio de Janeiro and 1: 1,400 in the states of Minas Gerais, Maranhão, Pernambuco and Goiás².

Advances in medicine and technology have reduced the mortality rate of children with SCD, however this disease is still associated with a shorter life expectancy in adults. One study looked at more than 16,654 deaths from SCD between 1979 and 2005, and found that the average life expectancy for women was 42 years and 38 years for men. The most common cause of death, among the complications of SCD, was infectious ${ }^{3}$. 
Complications of SCD are painful, chronic and/or acute, can occur early and extend throughout life. The most common are anemias, painful crises, recurrent infections, jaundice, splenic sequestration, acute chest syndrome, stroke, priapism, aplastic crisis, osteonecrosis and leg ulcers ${ }^{4}$. When considering the female gender, delayed menarche is added to the list of complications, in addition to complications in relation to pregnancy, since about $50 \%$ of pregnant women with SCD require at least one hospital stay. Even with current multidisciplinary care, mortality is increased ${ }^{5}$.

Leg ulcers occur in people of both genders and start acutely and often progress to chronic phases. This situation requires adequate management and demands financial resources for investment in products and inputs ${ }^{1}$.

The prevalence and incidence of leg ulcers varies geographically, with age and with the type of disease $\mathrm{e}^{6}$. The results of a study carried out in Nigeria portrayed these variations and found an incidence of $0.45 \%$ and a prevalence of $3.1 \%{ }^{7}$. Multicenter study carried out in three countries, involving 659 people with SCD, identified a $10.8 \%$ prevalence of leg ulcers, $18.6 \%$ in Ghana, $3.5 \%$ in Italy and $2.4 \%$ in the United States, and the largest part of leg ulcers occurred in adults with the HbSS genotype ${ }^{8}$.

Leg ulcers may appear after trauma or spontaneously, preferably in the malleoli, and may affect the entire circumference of the leg. They are extremely painful and difficult to heal, with evolution lasting for months to years and high rates of recurrence ${ }^{6}$. Ulcers are more common in the second decade of life and in males. They are associated with lower socioeconomic status and low education?

Leg ulcers, regardless of aetiology, may not represent a high risk of death for those who have them, but they affect people in the physical, psychosocial and emotional spheres, mainly due to its progressive and chronic character ${ }^{6}$. In view of this complexity, people with SCD and leg ulcers demand specialized services and professionals.

Although results of studies cite that ulcers are more common in men, reaching a proportion of $3: 1^{10}$ and $1,3: 1^{7}$, this is an important topic of discussion due to the impact it can have on the lives of female patients. Women who live with leg ulcers experience stressful situations arising from this chronic health problem, such as pain, odor, changes in daily activities, low self-esteem and gynecological changes ${ }^{11}$. It is also necessary to consider the change that the ulcer brings to their bodies, requiring a presentation of themselves to the public in order to keep the ulcer's existence in secret ${ }^{10}$.

The interaction between people with ulcers and health professionals is an essential element in the definition of care ${ }^{12}$. In this context, knowledge of the profile of women with leg ulcers due to SCD is important because it is a population that already has complications and concerns that are characteristic of this gender, such as planning reproductive life, pregnancy complications, as well as the care of a child with $\mathrm{SCD}^{5}$. Therefore, the question is: who are the women with leg ulcers treated at an outpatient clinic in a public service? The knowledge generated will support the planning of nursing actions, as well as improving the relationship between health professionals and women with leg ulcers.

Given the above, the study aims to characterize the profile of women with leg ulcers resulting from SCD treated at a public health institution in Brazil.

\section{METHODS}

This is a historical cohort study, involving the Stomatherapy sector of a dermatology outpatient clinic in a large tertiary university hospital in Belo Horizonte, Minas Gerais, Brazil. In this sector, the professionals responsible for direct care for people with ulcers are nurses who are specialists in stomatherapy or dermatology. The dressing change occurs once or twice a week according to the wound assessment. In this service, patients are treated according to the institutional protocol. For the management of edema, inelastic compression therapy (Unna boot) is standardized and as topical treatment the coverings called hydrocolloid, calcium alginate without silver (Ag), activated carbon with Ag or foam with Ag. 
The sample consisted of all women with SCD and leg ulcers, aged 18 years or older, attended from June 1998 to June 2014, when the women were admitted. During treatment, all patients used an Unna boot to manage edema and, as a topical treatment, one of the standard coverings at the institution.

Data collection was carried out from June to August 2020 by a researcher in the present study. The data were extracted from the patient's medical record and recorded in a form designed specifically for the research, including sociodemographic variables (age, color/race, marital status, education, family income, occupation, basic sanitation), clinics (body mass index [BMI], associated diseases, medications in use, smoking, alcoholism) and ulcer-related (number of ulcers, location, time of existence, period needed for healing, tissue impairment [stage 1: intact skin with unbleachable erythema; stage 2: partial loss of skin, involving the epidermis and reaching the dermis; stage 3: total loss of skin thickness, involving the subcutaneous tissue, which may extend to the underlying fascia] $)^{13}$. The collected data were entered into spreadsheets in the Excel program, version 14.7.7, in order to submit them to descriptive statistical analysis.

The research complied with the guidelines of Resolution No. 466, of December 12, 2012, of the National Health Council. The study project was approved by the Research Ethics Committee of the Universidade Federal de Minas Gerais under opinion No. 2,797.025/2018. The waiver of the Informed Consent Form was requested, since it is an observational study and the data were extracted from a secondary source.

\section{RESULTS}

In the period of 16 years, 17 women with leg ulcers resulting from SCD were admitted and treated in the Stomatherapy sector. Of these, 11 (64.7\%) reached complete ulcer epithelization, 3 (17.6\%) were transferred to other services, 2 (11.8\%) abandoned treatment and 1 (5.9\%) died .

Most women were between 30 and 39 years old, declared themselves to be brown, had no partner and had a family income of 2 to 3 minimum wages (Table 1). As for clinical variables, most were eutrophic, with no associated diseases, used vitamin supplements and did not smoke (Table 2).

Table 1. Distribution regarding sociodemographic variables of women with leg ulcers due to sickle cell disease $(n=17)$. Belo Horizonte (MG), Brasil - 2020.

\begin{tabular}{lc}
\hline Variables & $\mathbf{n = 1 7 ( \% )}$ \\
\hline Age (years) & $01(5.9)$ \\
\hline Up to 19 & $04(23.5)$ \\
\hline $20-29$ & $10(58.8)$ \\
\hline $30-39$ & $02(11.8)$ \\
\hline 40 or more & $11(64.7)$ \\
\hline Color/ Race & $05(29.4)$ \\
\hline Brown & $01(5.9)$ \\
\hline Black & $12(70.6)$ \\
\hline White & $05(29.4)$ \\
\hline Marital Status & \\
\hline No partner & $07(41.2)$ \\
\hline With partner & $03(17.6)$ \\
\hline Scholarity & $05(29.4)$ \\
\hline Incomplete elementary school & $01(5.9)$ \\
\hline Complete elementary school & $01(5.9)$ \\
\hline Complete high school &
\end{tabular}


Tabela 1. Continuation...

\begin{tabular}{lc}
\hline Variables & $\mathbf{n = 1 7 ( \% )}$ \\
\hline Family income (minimum wage) & $05(29.4)$ \\
\hline 01 & $09(52.9)$ \\
\hline $02-03$ & $00(0.0)$ \\
\hline >4-05 & $01(5.9)$ \\
\hline Uninformed & $02(11.8)$ \\
\hline Sanitation & $16(94.1)$ \\
\hline Present & $01(5.9)$ \\
\hline Absent & \\
\hline Occupation & $01(5.9)$ \\
\hline Student & $01(5.9)$ \\
\hline Administrative assistant & $05(29.4)$ \\
\hline Housewife & $04(23.5)$ \\
\hline Maid & $03(17.6)$ \\
\hline Receptionist & $01(5.9)$ \\
\hline Seamstress & $01(5.9)$ \\
\hline Microfilming operator & $01(5.9)$ \\
\hline Teacher (private lessons) &
\end{tabular}

Table 2. Distribution regarding the clinical variables of women with leg ulcers due to sickle cell disease $(n=17)$. Belo Horizonte (MG), Brasil - 2020.

\begin{tabular}{ll}
\hline Variables & $\mathbf{n}=17(\%)$ \\
\hline Smoking & $01(5.9)$ \\
\hline Yes & $16(94.1)$ \\
\hline No & $02(11.8)$ \\
\hline Alcoholism & $15(88.2)$ \\
\hline Yes & \\
\hline No & $04(23.5)$ \\
\hline BMI (kg/m²) & $12(70.6)$ \\
\hline$<18,5$ & $01(5.9)$ \\
\hline$\geq 18,5<25,0$ & $13(76.4)$ \\
\hline$\geq 25,0<30,0$ & $02(11.8)$ \\
\hline Associated diseases* & $01(5.9)$ \\
\hline None & $01(5.9)$ \\
\hline Arterial hypertension & \\
\hline Allergic rhinitis & $06(35.3)$ \\
\hline Cancer & $14(82.4)$ \\
\hline Medicines in use & $02(11.8)$ \\
\hline Analgesic & $02(11.8)$ \\
\hline Vitamin supplement & $02(11.8)$ \\
\hline Antihypertensive & $01(5.9)$ \\
\hline Antiplatelet & $02(11.8)$ \\
\hline Antidepressive & \\
\hline Chemotherapy & \\
\hline & \\
\hline Folic acid & \\
\hline
\end{tabular}

$\mathrm{BMI}=$ Body Mass Index. ${ }^{*}$ The variation in $\mathrm{n}$ is due to people having more than one associated disease. 
The 17 women had a total of 29 ulcers, of which $9(52.9 \%)$ had a single ulcer, 12 (41.4\%) were located in the malleolar region, 16 (55.17\%) with time of existence of the wound between 2 and 36 months, and in $9(31.04 \%)$ the time needed to achieve healing was 2 to 4 months (Table 3).

Table 3. Distribution of variables related to leg ulcers $(n=29$ in women with sickle cell disease $(n=17)$. Belo Horizonte (MG), Brasil - 2020 .

\begin{tabular}{|c|c|}
\hline Variable & $\mathrm{n}=17(\%)$ \\
\hline \multicolumn{2}{|l|}{$\mathrm{N}^{\circ}$ of ulcers } \\
\hline One & 09 (52.9) \\
\hline Two & $06(35.3)$ \\
\hline Three & $00(00)$ \\
\hline Four & $02(11.8)$ \\
\hline \multicolumn{2}{|l|}{ Placement } \\
\hline Medial malleolus & $12(41.4)$ \\
\hline Right lateral malleolus & $09(31.0)$ \\
\hline Lower third of the leg & $08(27.6)$ \\
\hline \multicolumn{2}{|l|}{ Tissue impairment } \\
\hline Stage 1 & $0(0)$ \\
\hline Stage 2 & $0(0)$ \\
\hline Stage 3 & $29(100)$ \\
\hline \multicolumn{2}{|c|}{ Time of existence of the injury } \\
\hline Less than 2 months & $1(3.44)$ \\
\hline From 2 to 36 months & $16(55.17)$ \\
\hline From 37 to 48 months & $1(3.45)$ \\
\hline From 49 to 60 months & $2(6.89)$ \\
\hline From 61 to 96 months & $3(10.34)$ \\
\hline$>96$ meses & $6(20.68)$ \\
\hline \multicolumn{2}{|c|}{ Time spent healing injuries } \\
\hline From 2 to 4 months & $9(31.03)$ \\
\hline From 4 to 8 months & $4(13.79)$ \\
\hline From 8 to 12 months & $6(20.69)$ \\
\hline$>12$ months & $2(6.89)$ \\
\hline Not applicable* & $8(27.59)$ \\
\hline
\end{tabular}

The topical treatments used for the treatment of ulcers were hydrocolloid plaque, calcium alginate, activated carbon with Ag and polyurethane foam with Ag. The edema was managed with an Unna boot.

\section{DISCUSSION}

In the present study, 2 (11.8\%) women were over 40 years old, the oldest being 43 years old. The finding corroborates the result of a French study with 98 people with SCD and active leg ulcers or with a previous history of ulcers, in which the average age was 37 years $(30-44)^{14}$. This information is relevant, considering that individuals born with SCD can live approximately 22 years less than a population of the same race / ethnicity and age without $\mathrm{SCD}^{15}$ and the average life expectancy for women is 42 years $^{3}$. 
Leg ulcers are an obstacle to the insertion of women in the labor market ${ }^{6}$, which may be associated with the fact that the women in this study have low schooling and low-paid jobs. However, it is noteworthy that the percentage of families headed by women has been increasing and, often, they have a central role in promoting the well-being of family members ${ }^{16}$.

Living with a chronic disease comprises a complex, cyclical, dynamic and constantly changing process that affects people in all spheres of their lives. It is known that women and men have a different perception of illness. While women emphasize physical appearance (altered self-image), men are concerned about loss of muscle strength, such as weakness ${ }^{12}$.

Women with SCD and leg ulcers experienced intense pain and feelings of shame and worthlessness, translated into suffering, low self-esteem and limitations in social life, which, in turn, can motivate isolation behavior ${ }^{11}$. These changes may justify the fact that the majority (70.6\%) of the study participants did not have partners. This characteristic was also found in a Brazilian study carried out with 14 women aged between 23 and 61 years old who had leg ulcers, and 85\% also had no partners ${ }^{17}$.

The African origin of SCD is reflected in the findings of this investigation, when it was found that $94.1 \%$ of women declared themselves black or brown. A similar data was identified as a result of a study conducted in Recife, Brazil, with 30 people with SCD, $80 \%$ of whom declared themselves to be black or brown ${ }^{18}$.

The level of education is central to many of the social consequences, a fact perceived in the women in the study and confirmed by another survey conducted with people with SCD whose education level was lower than that of people without the disease $(\mathrm{p}=0.020)^{19}$. This situation can be aggravated in the occurrence of leg ulcers, since it is known that its presence has deleterious effects in relation to education, employment, recreation and conjugal and family life. When comparing people with SCD with and without the ulcer, those with ulcers dropped out of school at a significantly younger age (14.4 years) than those without ulcers $(16.1)(\mathrm{p}<0.01)^{19}$.

It is unfortunate, but SCD is not a disease widely known in educational institutions, even when there are students with the diagnosis enrolled. This fact limits the school's involvement with the problems experienced by the student ${ }^{20}$, contributing to early evasion and reinforcing the relevance of education in changing social indicators.

When relating schooling, work activities and income, a vicious circle is perceived in which the clinical repercussions of the disease lead the subject to have low education and consequently low-paying jobs, thus perpetuating low income. When comparing people with and without SCD, the difference in family income is statistically significant, since a greater number of people with SCD have an income less than or equal to a minimum wage when compared with those without the disease ${ }^{18}$.

Result of an American study presents data proving that individuals with leg ulcers have worse physical function $(p=0.0022)$ and pain interferes more in their daily life $(0.0003)$ when compared to people with SCD without ulcers ${ }^{11}$. This chronic clinical condition negatively affects work activities and, consequently, income, since, in this study, $52.9 \%$ of women were housewives or domestic workers and $66.7 \%$ had family income of up to one minimum wage.

Recreation patterns of people with SCD are generally affected and they tend to be sedentary ${ }^{21}$. However, in this survey, only 5.9\% were overweight. The National Health Service of England recommends referring overweight or obese people to the multiprofessional team for adoption of behavioral interventions ${ }^{5}$.

Women with SCD are more prone to complications when compared to women without $\mathrm{SCD}^{5}$. However, in the present study, 23.6\% of women had systemic arterial hypertension, cancer or allergic rhinitis. It is important that during the nursing consultation the professional makes a careful anamnesis, since the healing of skin lesions is affected by systemic factors, such as age, vascularization, systemic medication, nutritional status, smoking and primary disease 9 .

One of the drugs, until now considered the most effective drug therapy in preventing crises and complications in people with SCD, is hydroxyurea, its use reduces the risk of death from SCD and significantly decreases the annual number of acute pain episodes in adults, but a possible side effect are leg ulcers ${ }^{22}$. In view of so many benefits, it appears in this research that no woman used this medication. This fact is probably due to the suspicion of hydroxyurea causing leg ulcers in patients with SCD. However, this side effect remains controversial ${ }^{23}$, including in a systematic 
review of the literature, hydroxyurea treatment of people with SCD was not significantly associated with an increase in the occurrence of leg ulcers ${ }^{22}$.

People with SCD face another situation of suffering, which are chronic sickle cell pain syndromes that include leg ulcers $^{4}$. They are painful and often disabling complications. Ulcer pain is generally classified as moderate to severe14 and most of the time oral or parenteral opioids are needed to get pain relief ${ }^{13}$. In the investigation of this study, $35.3 \%$ of women used painkillers, a lower figure than that found in a study carried out in Africa with 40 people with leg ulcers, which was $80 \%{ }^{24}$. The data related to the prescription of analgesics for women in this study may indicate undertreatment of pain. People with SCD and chronic pain can have serious psychological problems, even causing them to withdraw from social activities, and their management requires health professionals to be patient, understanding and empathetic throughout the treatment ${ }^{4}$.

As for the characteristics of the ulcers, they have well-defined margins, slightly elevated edges and a bed covered, predominantly, by slough intermingling the pale red granulation tissue. They can be classified as acute, when they heal in less than a month, and chronic, otherwise ${ }^{25}$. In this study, all injuries were classified as stage $3^{13}$, since they had total loss of skin thickness, they involved the subcutaneous tissue and extended to the underlying fascia, however they did not compromise deeper structures.

Ulcers occur more frequently around the medial and lateral malleoli, but they can also appear in the anterior tibial region and on the dorsum of the foot. The predilection factors for ulcer by the malleolus are reduced local blood flow, high venous pressure, less subcutaneous fat, thin skin and lymphedema ${ }^{13}$.In this study, $72.4 \%$ of the ulcers were present in the regions of the medial and/or lateral malleoli, given that it corroborates findings whose ulcer predilection was in the malleolus region in $86 \%{ }^{7}$ and $66.7 \%{ }^{10}$ of the cases.In addition to the predilection for the malleolus region, ulcers are generally unique in $58 \%{ }^{10}, 76 \%{ }^{24}$ and $69 \%{ }^{14}$ of people. In this investigation, $52.9 \%$ of women had an ulcer, a lower percentage when compared to the studies cited.

In the present study, the wounds were classified as chronic with a lifetime between 2 months and 10 years, with 55.17\% lasting between 2 and 18 months. A study carried out in Nigeria presented similar data, around 79\% of the participants had ulcer duration between 7 and 18 months $^{7}$. A multicenter study carried out in Ghana, Italy and the United States, involving 659 people with SCD, identified an average duration of leg ulcers of 4.6 years and the longest average duration was 7.25 years $^{8}$, different from the present study, in which $20.68 \%$ of participants had ulcers for more than 10 years.

The duration of the ulcer is a predictive factor for healing. The duration of less than 9 weeks was significantly $(p=0.024)$ associated with a greater chance of cure, with odds ratio $3.19(1.16-8.76)^{14}$. Six months of existence define recalcitrant ulcers ${ }^{13}$.

Among the participants in this study who obtained a cure, 31.03\% required 2 to 4 months, with appropriate topical treatment and edema control, according to the recommendations for the management of leg ulcers in people with $\mathrm{SCD}^{26}$. Topical treatment of ulcers involved the use of coverings, such as hydrocolloid plaque, calcium alginate, activated carbon with $\mathrm{Ag}$ and polyurethane foam with Ag. These products keep the environment moist, promote the debridement of devitalized tissue and control the bacterial load or infection ${ }^{5}$.

The edema was managed using the Unna boot. It is known that venous insufficiency is often observed in people with SCD, therefore, in addition to topical treatment of the ulcer, it is necessary to manage the edema of the leg with the use of restraint therapies (Unna boot) or compression therapies ( components), the latter being the first choice ${ }^{6,5}$.

It is worth noting that the sample size was a limitation of the study, imposed by the small number of women admitted to the study setting, thus the external validity is compromised. However, the results of the research contributed to know the sociodemographic and clinical profiles of women with SCD, including the characteristics of ulcers. They also allowed to establish a dialogue with the literature data, considering the convergences and divergences. As a result, the knowledge generated revealed gaps, including the low scientific production on the subject treated: women with SCD and leg ulcers. 
Another benefit obtained through information extracted from the medical record, previously collected during the consultation performed by the nurse, and analyzed in this study is that they allow the examiner to assess which behaviors need health education interventions. In addition, it makes it possible to follow the recommendations for the treatment of leg ulcers resulting from SCD and to demystify the lack of cure for these skin lesions.

\section{CONCLUSION}

The 17 women with SCD had 29 ulcers, the majority of whom had a single ulcer and the time the wound existed between 2 and 36 months. In the Stomatherapy sector where the study was carried out, women received care from specialist nurses and most of them were cured with up to eight months of follow-up, which required nursing consultation, including clinical evaluation, topical treatment and application of compression therapy. Vitamin supplements were the most used medications. Most women were in the age group between 30 and 39 years old, declared themselves black / brown and had no partner. Schooling and family income were low.

It is noteworthy that this study focused on sociodemographic and clinical data of women with leg ulcers. Considering the complexity that the ulcer entails in the lives of these people, it was realized the need to carry out qualitative studies that address the psychosocial issues brought about by the presence of the ulcer.

\section{AUTHOR'S CONTRIBUTION}

Conceptualization: Borges EL and Andrade PG; Methodology: Borges EL, Spira JAO and Andrade PG; Writing First Version: Spira JAO, Andrade PG and Gomes ML; Writing - Review \& Editing: Andrade PG, Spira JAO, Borges EL and Gomes ML; Supervision: Borges EL.

\section{DATA AVAILABILITY STATEMENT}

The research data will be sent upon request and after approval by the authors.

\section{REFERENCES}

1. Sundd P, Gladwin MT, Novelli EM. Pathophysiology of Sickle Cell Disease. Annu Rev Pathol 2019;14:263-92. https://doi. org/10.1146/annurev-pathmechdis-012418-012838

2. Ministério da Saúde (BR). Doença falciforme: condutas básicas para tratamento. Brasília(DF): Secretaria de Atenção à Saúde; 2012.

3. Lanzkron S, Carroll P, Jr Haywood C. Mortality Rates and Age at Death from Sickle Cell Disease: U.S., 1979-2005. Public Health Rep 201;128(2):110-116. https://doi.org/10.1177/003335491312800206

4. Ballas SK, Darbari DS. Review/overview of pain in sickle cell disease. Complement Ther Med 2020;49:102327. https://doi. org/10.1016/j.ctim.2020.102327

5. National Institutes of Health (NIH). Evidence-based management of sickle cell disease: expert panel report 2014.2014. [cited on 28 nov 2020]. Available at: https://www.nhlbi.nih.gov/sites/default/files/media/docs/sickle-cell-disease-report\%20 020816_0.pdf

6. Minniti CP, Kato GJ. How we treat sickle cell patients with leg ulcers. Am J Hematol 2016;91(1):22-30. https://doi.org/10.1002/ ajh.24134

7. Hassan A, Gayus DL, Abdulrasheed I, Umar MA, Ismail DL, Babadoko AA. Chronic leg ulcers in sickle cell disease patients in Zaria, Nigeria. Arch Int Surg 2014;4(3)141-45. https://doi.org/10.4103/2278-9596.146405

8. Antwi-Boasiako C, Andemariam B, Colombatti R, Asare EV, Strunk C, Piccone CM et al. A study of the geographic distribution and associated risk factors of leg ulcers within an international cohort of sickle cell disease patients: the CASiRe group analysis. Ann Hematol 2020;99(9):2073-79. https://doi.org/10.1007/s00277-020,-04057-8 
9. AIDallal SM. Mini review: leg ulcers - a secondary complication of sickle cell disease. Int J Gen Med 2019;12:279-82. https://doi. org/10.2147/IJGM.S217369

10. Bazuaye GN, Nwannadi Al, Olayemi EE. Leg ulcers in adult sickle cell disease patients in Benin city, Nigeria. Gomal Journal of Medical sciences 2010; [cited on 26 nov 2020];8(2):190-4. Available at: https://www.researchgate.net/publication/216180367_ Leg_Ulcers_in_Adult_sickle_cell_disease_patients_in_Benin_City_Nigeria

11. Umeh NI, Ajegba B, Buscetta AJ, Abdallah KE, Minniti CP, Bonham VL. The psychosocial impact of leg ulcers in patients with sickle cell disease: I don't want them to know my little secret. PLoS One 2017;12(10):e0186270. https://doi.org/10.1371/journal. pone.0186270

12. Cordeiro RC, Ferreira SL, Santos ACC. O adoecimento de mulheres e homens com anemia falciforme: um estudo de Grounded Theory. Rev Latino-Am Enfermagem 2015;23(6):1113-20. https://doi.org/10.1590/0104-1169.0594.2656

13. Minniti CP, Eckman J, Sebastiani P, Steinberg MH, Ballas SK. Leg ulcers in sickle cell disease. Am J Hematol 2010;85(10):831-3. https:/doi.org/10.1002/ajh.21838

14. Senet $P$, Blas-Chatelain C, Levy P, Manea EM, Peschanski M, Mirault T et al. Factors predictive of leg-ulcer healing in sickle cell disease: a multicentre, prospective cohort study. Br J Dermatol 2017;177(1): 206-11. https://doi.org/10.1111/bjd.15241

15. Lubeck D, Agodoa I, Bhakta N, Denese M, Pappu K, Howard R et al. Estimated Life Expectancy and Income of Patients With Sickle Cell Disease Compared With Those Without Sickle Cell Disease. JAMA Netw Open 2019;2(11):e1915374. https://doi. org/10.1001/jamanetworkopen.2019.15374

16. Cavenaghi S. Mulheres chefes de família no Brasil: avanços e desafios. Rio de Janeiro: ENS-CPES, 2018; [cited on 26 nov 2020] Estudos sobre seguros, $\mathrm{n}^{\circ}$ 32. Disponivel em: https://www.ens.edu.br/arquivos/mulheres-chefes-de-familia-no-brasil-estudosobre-seguro-edicao-32_1_2.pdf

17. Lacerda FKL, Ferreira SL, Nascimento ER, Costa DO, Cordeiro RC. Self-care deficits in women with leg ulcers and sickle cell disease. Rev Bras Enferm 2019;72(Suppl 3):78-85. http://doi.org/10.1590/0034-7167-2018-0005

18. Alexandre MRA, Pedrosa EN, Soares PHS, Wanderley MM, Melo RVM, Correa MSM et al. Qualidade de vida de mulheres com doença falciforme atendidas em um hospital terciário no Recife, Brasil. R bras Qual Vida 2019; [cited on 24 nov 2020]; 11(3):e10156. Available at: http://periodicos.utfpr.edu.br/rbqv

19. Lima KTLL, Pereira JOF, Reis PRM, Alcântara KC, Rodrigues FM. Qualidade de vida dos portadores de doença falciforme. Rev enferm UFPE on line 2019;13(2):424-30. Available at: https://pesquisa.bvsalud.org/portal/resource/pt/biblio-1010204

20. Rodrigues WCC, Seibert CS, Silva KLF. Um olhar sobre a formação do aluno com doença falciforme. Desafios (Palmas) 2017;4(1):86-94. http://doi.org/10.20873/uft.2359-3652.2017v4n1p86

21. Kaufman K, Chin S-H, Kahathuduwa C, Wood MMA, Feliu M, Hill L et al. Psychosocial Correlates, Pain and Activities of Daily Living in Sickle Cell Disease Patients. Progress in Preventive Medicine 2018;3(4):e0019. https://doi.org/10.1097/pp9.0000000000000019

22. Nevitt SJ, Jones AP, Howard J. Hydroxyurea (hydroxycarbamide) for sickle cell disease. Cochrane Database Syst Rev 2017;4(4):CD002202. https://doi.org/10.1002/14651858.CD002202.pub2

23. Monfort J-B, Senet P. Leg Ulcers in Sickle-Cell Disease: Treatment Update. Adv Wound Care (New Rochelle) 2020;9(6):348-56. https://doi.org/10.1089/wound.2018.0918

24. Ndiaye M, Niang SO, Diop A, Diallo M, Diaz K, Ly F et al. Leg ulcers in sickle cell disease: A retrospective study of 40 cases. Ann Dermatol Venereol 2016;143(2):103-7. http://doi.org/10.1016/j.annder.2015.12.004

25. Singh AP, Minniti CP. Leg ulceration in sickle cell disease: an early and visible sign of end-Organ Disease. Sickle Cell Disease Pain and Common Chronic Complications 2016. http://doi.org/10.5772/64234

26. Borges EL, Spira JAO, Garcia TF. Recomendações para o manejo da úlcera da perna em pessoas com doença falciforme. Rev enferm UERJ 2020;28:e50170. https://doi.org/10.12957/reuerj.2020.50170 